\title{
A magyarországi földikutya-áttelepítések értékelése
}

\author{
Ruzsa János ${ }^{1}$, Schneider Viktor ${ }^{2}$, Farkas János ${ }^{1}$ és Németh Attila ${ }^{3,4}$ \\ ${ }^{1}$ Eötvös Loránd Tudományegyetem, Állatrendszertani és Ökológiai Tanszék \\ 1117 Budapest, Pázmány Péter stny. 1/C \\ ${ }^{2}$ Szent István Egyetem, Mezögazdaság- és Környezettudományi Kar, \\ 2100 Gödöllö, Páter Károly u. 1. \\ ${ }^{3}$ Magyar Madártani és Természetvédelmi Egyesület, \\ 1121 Budapest, Költö u. 21. \\ ${ }^{4}$ Magyar Természettudományi Múzeum, \\ 1088 Budapest, Baross u. 13. \\ E-mail: dr.attila.nemeth@gmail.com
}

Összefoglaló: A nyugati földikutyák, Nannospalax (superspecies leucodon) Magyarország legveszélyeztetettebb emlősállatai közé tartoznak. Sajátos életmódjuk miatt megörzésük különösen nehéz feladatot jelent a természetvédelem számára. 2013 óta összesen négy áttelepítés történt, amelyek célja új populációk létrehozása, így az állományok számának növelése, ezáltal pedig a földikutyák természetvédelmi helyzetének, hosszútávú fennmaradásuk esélyeinek javítása volt. Az áttelepítések - kezdő évük szerinti sorrendben - Bagamér (2013), Pocsaj (2015), Öttömös (2016) és Baja (2017) települések közelében történtek. Az egyes akciók sikerességének értékelése mellett igyekeztünk magyarázatot találni az áttelepítések eredményessége között megfigyelhető jelentős különbségekre is. $\mathrm{Az}$ áttelepítés helyszínének sajátságai éppolyan fontos befolyásoló tényezőnek bizonyultak, mint az előzetesen kidolgozott protokoll pontos követése. Reményeink szerint a bemutatott eredmények hozzájárulnak a jövőbeli sikeres akciók végrehajtásához.

Kulcsszavak: Nannospalax (superspecies leucodon), élőhely-alkalmassági vizsgálat, monitoring, Bagamér, Pocsaj, Öttömös, Baja

\section{Bevezetés}

Az emberi tevékenység hatására bekövetkezö biodiverzitás-csökkenés napjainkra riasztó mértéket öltött, így ez korunk egyik legjelentősebb környezeti problémája (Ceballos et al. 2010, Barnosky et al. 2011, McGill et al. 2015). A probléma azonban nem újkeletü, több száz jól dokumentált eset ismert a történelem előtti és történelmi időkből, amikor az ember okozta egy-egy faj vesztét (Baillie \& Cokeliss 2004, Dirzo et al. 2014). Ennek ellenére az emberiségnek ezidáig nem sikerült 
eszközt találnia a probléma megoldására. A kedvezőtlen folyamatok következményei többnyire nem, vagy csak kivételes erőfeszítésekkel állíthatók helyre (Vida 2018).

Hazánk történetében a természetvédelemnek mélyen gyökerező hagyományai vannak (Andrési 2002, Hadarics 2011), azonban így sem sikerült megakadályozni megannyi faj jelentős mértékü visszaszorulását, sőt kipusztulását (Rakonczay 1989). Mindezen okok miatt a természetvédelmi erőfeszítések globális szinten jelentős eszközét képviselő vissza- és áttelepítések (Griffith et al. 1989, Pullin \& Bajomi 2008, Seddon et al. 2007) az utóbbi időkben a hazai természetvédelemben is mind gyakoribb megoldásokká váltak (Olajos 2012).

Bár az át- és visszatelepítési programok nem mentesek a kockázatoktól, és nem minden veszélyeztetett faj számára jelentik a legjobb megoldást, mégis a jól felépített visszatelepítési programok nyújthatják a legtöbb esélyt a természetes élőhelyén a kihalás szélére sodródott vagy rohamosan fogyatkozó egyedszámú fajok számára (Reading \& Kellert 1993). Éppen ezért nem meglepő, hogy már az 1980-as években, csupán Észak-Amerikában, évente 700 áttelepítési program valósult meg (Griffith et al. 1989). Az IUCN (Természetvédelmi Világszövetség) áttelepítésekre szakosodott szakosztályának (Re-Introduction Specialist Group) adatbázisa szerint közel 500 állatfajt érintenek a már zajló vagy a közeljövőre tervezett áttelepítési akciók (Seddon et al. 2007). A 20. század végéig a legkülönfélébb gazdasági megfontolásokból, vadászati, halászati célokból számos faj betelepítésére került sor Magyarországon (Márkus 2004). Az 1970-es évektől azonban egy új tudományág, a természetvédelmi biológia (is) kezdett teret hódítani hazánkban (Sterbetz 1979), így a zárttéri szaporítás, a visszavadítás, a visszatelepítés, a mentés jellegü áttelepítés mind inkább része lett a hazai természetvédelmi gyakorlatnak (Márkus 2004). Számos faj hazai át- és visszatelepítésére került sor, meglehetősen változatos eredménnyel (Bajomi 2003). Az érintett fajok is széles rendszertani skálán mozogtak, melyek közül a jelen publikáció témája kapcsán számunkra érdekes rágcsálókat a hazai telepítési gyakorlatban sokáig csupán két faj, az ürge és a hód képviselte (Olajos 2012). Míg a hód visszatelepítése egyetlen, sikeres program keretében valósult meg (Bajomi et al. 2016), addig az ürge esetében számos különböző, egymástól független akcióra került sor az 1970-es évek végétől napjainkig. Az idők során a programok céljai és az akciók módszertana, kivitelezése is jelentősen változott. Ráadásul az ürge-áttelepítések sikeressége is változatos képet mutat: míg a 2000 elött áttelepített állományok közül egy sem maradt fenn 2016-ig, addig a 2000 után végrehajtott áttelepítések közel a fele (47\%-a) tekinthető hosszú távon sikeresnek (Fidlóczky et al. 2017).

A hazai rágcsálók talán legveszélyeztetettebb csoportját a Kárpát-medence bennszülött, nyugati földikutya (Nannospalax (superspecies leucodon) Nordmann, 1840) fajcsoportba tartozó földikutyafajai képviselik (Csorba et al. 2015, 
Németh et al. 2013a). Ezek a talajlakó életmódhoz tökéletesen alkalmazkodott állatok (Topachevskii 1969, Vidacs et al. 2013), sajátos testfelépítésük és különös életmódjuk miatt a hazai emlősfauna egyedülálló tagjai (Vásárhelyi 1926). Bár egykor széles körben elterjedtek voltak Magyarországon, élőhelyeik átalakításának és megszünésének következtében kritikus helyzetbe kerültek (Németh et al. 2013a). Veszélyeztetettségük ellenére ismert hazai előfordulási helyeiknek csupán kevesebb, mint a fele élvez védelmet (Csorba et al. 2015), ugyanakkor számos veszélyeztető tényező fenyegeti állományaik fennmaradását (Németh et al. 2013a). A földikutya-populációk jelentős része pedig olyan élőhelyeken található, ahol e fokozottan védett kisemlős megörzése az állami természetvédelem számára különösen nagy gondot jelent (Németh et al. 2020). A hazai földikutyafajok hosszú távú fennmaradásának biztosításához azonban minden, még létező populációra szükség van Magyarországon (Németh et al. 2013a). Ezért lehetséges megoldásként már viszonylag korán felmerült a földikutya-egyedek áttelepítése (Németh et al. 2010). Mivel azonban a szakirodalom alapján a földikutyák (vagy más, hasonlóan szélsőséges talajlakó életmódot folytató kisemlősök) áttelepítésére korábban még sehol a világon nem volt példa (Németh et al. 2013b), e beavatkozás gondolata sokáig csupán elméleti lehetőség maradt. Végül 2012-ben vette kezdetét a földikutya-áttelepítés módszertanának kidolgozása. A megszületett protokoll (Németh et al. 2013b) számos szempontot figyelembe vesz, és részletesen kitér a földikutya-áttelepítés során felmerülő kérdésekre és/vagy problémákra, az áttelepítési helyszín kiválasztásától a létrejövő új állomány monitorozásáig. A kidolgozott módszertan segítségével 2013 és 2014 között egy rendkívül sikeres akció zajlott, melynek során egy teljesen új, azóta önállóan is életképes populációt sikerült létrehozni védett területen, Bagamér közelében (Moldován 2014). Mindez arra bátorította a szakembereket, hogy a fokozott veszélynek kitett élőhelyeken fennmaradt állományok egyedeit is jobban védhető területekre próbálják menekíteni. Így vette kezdetét egy belterületi állomány egyedeinek befogása Debrecenben, és áttelepítésük egy Pocsaj közelében fekvő Natura 2000 besorolású területre. Hasonló akciók kezdődtek később a Kiskunsági Nemzeti Park Igazgatóság müködési területén is, Öttömös közelében (Németh et al. 2018), valamint Baján (Schneider et al. 2019).

Az elvégzett földikutya-telepítések eredményei változatos képet mutatnak, ugyanakkor mindeddig csupán két akció szakmai értékelésre került sor (Moldován 2014, Schneider et al. 2019). Az egyes akciók összehasonlítása, eredményességük egységes szempontrendszerü, átfogó értékelése ez idáig váratott magára. Természetvédelmi szempontból azonban jelentős kérdésről van szó, hiszen a sikeresen és hatékonyan végrehajtható földikutya-telepítések csökkenthetik a kiszemelt földikutyafaj sérülékenységét azáltal, hogy növelik a populációi számát és jelentősen 
növelhetik a földikutyákra vonatkozó ismereteink körét is. Amennyiben sikerül a természetvédelmi gyakorlatban rutinszerüen alkalmazható áttelepítési módszert kidolgozni a hazai földikutyákra, az később akár a világ más tájain élő további talajlakó kisemlősökön is segíthet. Jelen publikációban ezért áttekintjük és értékeljük az eddigi négy földikutya-áttelepítés folyamatát és eredményét. Összegezzük eddigi tapasztalatokat, megpróbáljuk meghatározni a sikerek és kudarcok okait, valamint ajánlásokat fogalmazunk meg a jövőbeli hatékonyabb áttelepítési akciók érdekében.

\section{Módszerek}

\section{A monitorozás módszertana}

A vizsgálatok és az értékelések során felhasznált állományadatok a létrehozott új populációk monitoringjának eredményeiből származnak. A monitorozás során a földikutyatúrásokat, azok mennyiségének és térbeli-, időbeli eloszlásának változásait követtük nyomon. Az áttelepítések után, az első túrások megjelenésétől kezdve naponta-kétnaponta GPS készülékkel (Garmin Oregon 600) rögzítésre kerültek a földikutyatúrások koordinátái, mintegy 3-4 héten keresztül. Ezt az időszakot követően további 1 évig minimum havi rendszerességú monitorozás zajlott az új populációk élőhelyein. Annak érdekében, hogy minden túrás csak egyszer kerüljön felmérésre, a már rögzített pozíciójú halmokat elsimítottuk. Mindez abban is segített, hogy az ugyanazon a helyen történő újbóli rátúrások is egyértelmüen észlelhetőek legyenek. A túrások helyzetét értékelve nyomon követhető az állatok aktivitása, elmozdulása és vándorlása a területen.

Az egyedek szabadon bocsátását követő második évben már nem azonosíthatóak egyedi szinten az áttelepített földikutyák. Az állomány felmérésére ekkor már nem a szabadon engedési helyektől kiindulva került sor, hanem az élőhely egészére kiterjedően, a területek térképére ráhelyezett négyzetrácsháló segítségével, vonalas felmérési módszer szerint történt az állomány egyedszámának meghatározása. A földikutyák magányos életmódot folytató, territóriumokat elszántan védelmező állatok (Vásárhelyi 1926), ezért az egymás szoros közelségében lévő túrásokat egy egyedtől származó életnyomnak tekintettük.

A földikutyák szaporodásáról szintén a túrások, valamint az egyedek aktivitási mintázata árulkodik. A földikutyák egész éves nyomon követése során az egyedek megnövekedett aktivitása révén jól azonosítható a párzás, valamint az utódgondozás időszaka. A fiatalok szétterjedésének idején (nyár elején), a szembetűnően megnövekedő aktivitás mellett bizonyos túrás-morfológiai jellegzetességek is utalhatnak az azévi szaporulatra (Moldován 2014). Egy adott helyen történő 
többszöri feltúrás, a dupla vagy háromszoros túrások azt mutatják, hogy a földikutya-egyed jelentős járatépítési tevékenységet folytat. Jellemzően az áttelepítést követően, az elengedés után készítenek ilyeneket az egyedek, amikor új élőhelyükön, az új járatrendszerük kiépítésén dolgoznak, de a nyár során megfigyelhető hasonló túrások szétterjedő fiatalok jelenlétére utalnak (Moldován 2014), akik a szülőtől való elválás részeként, az anya járatrendszeréből kiindulva saját járatrendszert készítenek maguknak (Rado et al. 1992).

A monitorozás során gyüjtött adatok térinformatikai feldolgozása és értékelése a Quantum GIS program segítségével történt (QGIS Development Team 2013).

\section{Az áttelepitések sikerességének vizsgálatára alkalmazott módszerek}

Az áttelepítések megítélését a sikeresség mérésére használt módszerek is befolyásolhatják (Wolf et al. 1996), ezért a szakirodalom szerint javasolt elsősorban demográfiai paramétereket figyelembe venni a sikeresség megállapításához (Seddon 1999), mint:

(i.) a kiengedett generáció túlélése,

(ii.) a kiengedett generáció és utódainak szaporodása, valamint

(iii.) a létrehozott populáció hosszú távú megmaradása.

Vizsgálatunk során ezért - kisebb módosításokkal - az Olajos (2012) által a hazai visszatelepítési programok értékelésére már használt módszert alkalmaztuk. Az általa követett, a sikeresség értékelésére szolgáló módszer (Lee és Hughes 2008) használata mellett ugyanakkor a sikerek és kudarcok okainak feltárására is kísérletet tettünk. Ez utóbbi esetében azt vizsgáltuk, hogy az egyes akciók megvalósításakor milyen mértékben követték különféle, széles körben elfogadott, vagy éppen az érintett állatcsoport esetében releváns áttelepítési útmutatók ajánlásait. Az IUCN áttelepítési útmutatójának követése és az adott áttelepítési akció sikeressége közötti kapcsolat vizsgálatának részletes szakirodalma van (Lee és Hughes 2008, Olajos 2012). A hazai szakemberek által kidolgozott földikutya-telepítési útmutatóban (Németh et al. 2013b) megfogalmazott ajánlások pedig pont az új földikutya-populációk sikeres létrehozása érdekében születtek meg. Mindezek mellett, az egyes akciók eredményességének értelmezése és értékelése céljából az élőhelyekhez kapcsolódó háttéradatok (élőhelyi jellemzők) széles spektruma is megvizsgáltuk.

\section{A telepitések sikerességi mutatójának kiszámitása}

Az új földikutya-állományok létrehozását célzó természetvédelmi beavatkozások sikerességének értékeléséhez egy Lee és Hughes (2008) által kidolgozott, és Olajos (2012) által a hazai viszonyok között már kipróbált, értékelési rendszert módosítottuk úgy, hogy az a földikutyák sajátos jellemzői mellett is használható legyen 
(1. melléklet). A szerzőpáros által eredetileg használt hat kritérium közül az első a telepítés minőségének az indikátora, a következő három a kialakuló új populáció sikerességét méri, az ötödik a projekt eredeti céljaihoz képest elért eredményt, a hatodik pedig az új populáció hosszú távú sikerességét vizsgálja. A módosított értékelési rendszerünkben az első pont, vagyis a szabadon engedett egyedek száma változatlanul szerepel. A létrejövő új populáció sikerességének mérésére viszont négy kritériumot használtunk: Az áttelepítés folyamatát közvetlenül túlélt egyedek arányának mérése mellett bekerült az első évet túlélők arányának vizsgálata is, ezenkívül megmaradt a szaporodás meglétére vonatkozó kérdés, valamint az új populáció növekedési rátáját vizsgáló pont. E demográfiai jellegü paraméterek vizsgálata talán a leghatékonyabb módja annak, hogy a létrejött új populáció életképességét, az új élőhely elfoglalása során mutatott sikerességét meghatározzuk (Seddon 1999).

A soron következő mindkét kérdés az új populáció hosszú távú sikerességét vizsgálja azáltal, hogy az önfenntartó populáció meglétére, illetve az állomány gyarapodásának mértékére kérdez rá. Mivel olyan földikutya-populáció, melynek mérete 500 egyedet meghaladó, sajnos mindössze egyetlen található hazánkban az egyébként önfenntartónak és stabilnak tartott állományok között is (Csorba et al. 2015), így ezen kritérium használata a földikutyák esetében kevéssé lett volna reális. A több mint 500 egyedből álló önfenntartó populáció (Beck et al. 1994) megléte, mint kritérium helyett ezért az áttelepített egyedek számához viszonyított jelenlegi populációméretre kérdezünk rá. Az általunk használt értékelési rendszerben 12 volt az elérhető maximális pontszám, a minimum pedig 0 .

\section{Az IUCN áttelepitési javaslataival való egyezés meghatározása}

A földikutya-áttelepítési akciók eredményessége mögötti okok feltárásához szintén használtunk egy, Lee és Hughes (2008) által kidolgozott rendszert. A módszer az egyes telepítési akciókat aszerint pontozza, hogy azok az általános áttelepítési útmutatók közül legszélesebb körben használt, IUCN telepítési útmutatójában megfogalmazott ajánlásokkal (IUCN/SSC 1998, 2013) milyen mértékben mutatnak egyezést. E módszert korábban már sikeresen alkalmazták hazai telepítési programok értékelésére (Olajos 2012). Az eredeti értékelési rendszert azonban kissé módosítottuk (2. melléklet) úgy, hogy a földikutya-telepítések szempontjából nem releváns pontokat kihagytuk belőle. Ezáltal az eredetileg használt 43 helyett, csupán 41 kritérium (39 előírás és 2 javaslat) maradt az értékelési rendszerben. Minden kérdésre nullától négy pontig értékelhető választ lehet adni. Az IUCN útmutatóval való teljes egyezés négy, a részleges három, kettő vagy egy pontot ér, míg az útmutatóban leírtaktól való teljes eltérés nulla pontot jelent. A két, az útmutatóban megfogalmazott javaslat után, annak követése esetén további 1-1 pont járhat. Az IUCN útmutatójában található összes kötelező kritérium 
egyenlő fontossággal szerepel, így a javaslatra kapható pontokkal együtt, összesen 158 pont érhető el. Ebből 86 a telepítést megelőző tevékenységekre, 40 az elökészületekre, tervezésre és a telepítésre magára, valamint 32 a telepítés utáni tevékenységre adható.

\section{A földikutya-telepitési útmutató javaslataival való egyezés meghatározása}

Mivel a legelső földikutya-áttelepítést megelőzően készült egy rendkívül alapos földikutya-telepítési útmutató (Németh et al. 2013b), ezért fontosnak tartottuk megvizsgálni azt is, hogy miként befolyásolta az áttelepítések sikerességét az útmutatóban megfogalmazott ajánlások minél pontosabb követése. Ennek vizsgálatára összeállítottunk egy, a Lee és Hughes (2008) által kidolgozott és az IUCN áttelepítési javaslataival való egyezés meghatározása szolgáló rendszerhez nagyon hasonló, de önálló értékelési rendszert (3. melléklet). A kidolgozott módszer tehát az egyes telepítési akciókat aszerint pontozza, hogy azok a földikutya-telepítési útmutatóban megfogalmazott ajánlásokkal mekkora mértékben mutatnak egyezést. Azonban az értékelési rendszerünkben nem csupán egy-egy megalapozó vizsgálat megléte vagy hiánya szerepel kritériumként, de a vizsgálat eredményére vonatkozó kérdéseket is elhelyeztünk. Amennyiben az akció előkészítése során nem került sor ezeknek a vizsgálatoknak az elvégzésére, abban az esetben ezeket utólag pótoltuk. Az általunk kidolgozott értékelési rendszer összesen 36 kritériumot tartalmaz. Minden kérdésre nullától négy pontig értékelhető választ lehet adni: a földikutya-telepítési útmutatóval való teljes egyezés négy, a részleges három, kettő vagy egy pontot ér, míg az útmutatóban leírtaktól való teljes eltérés nulla pontot jelent. Az összes kritérium egyenlő fontossággal szerepel, így összesen 144 pont érhető el. Mindez úgy áll össze, hogy az áttelepítési helyszín kiválasztása 56, a befogások helyszíneinek kiválasztására 20, a befogások kivitelezésének kérdéseire 24, az ideiglenes tartás metodikájára 4, a szabadon bocsátás kivitelezésére 12, az ellenőrzés és monitoring kérdéseire pedig 28 pont adható.

\section{Élőhelyi jellemzők vizsgálata}

Az egyes áttelepítési akciók eredményének megértéséhez, valamint az akciók során szerzett pozitív vagy negatív tapasztalatok okainak feltáráshoz szükség volt a forrásállományok régi élőhelyeinek, valamint az új élőhelyek jellemzőinek összehasonlító vizsgálatára. A vizsgálatokat bizonyos áttelepítési akciók előkészítése során már elvégezték, más esetekben viszont ezek elmaradtak, így utólagos pótlásuk vált szükségessé.

A tájtörténeti vizsgálatok elvégzésére a Katonai Felmérések (Első (1783), Második (1858) és Harmadik (1881)) térképlapjai (http1-3), valamint a II. Világháború idején (1941) készült (http4) katonai térképezések nyújtottak lehetőséget. Az elmúlt fél évszázad során (1959-2007) az élőhelyeken zajlott változásokat 
a Lechner Nonprofit Kft. légifilmtárában található felvételek (http5) segítettek megismerni. A legutóbbi két évtized változásait a Google Föld program korábbi térképeinek („,örténelmi térképek”) vizsgálata tette lehetővé (Google Earth Pro, ver. 7.3.2.5776).

Fontos volt a területek talajtani és domborzati jellemzőinek összehasonlítása is. Az érintett területek mikrodomborzatának vizsgálatához a Földmérési és Távérzékelési Intézet (FÖMI) 1:10000 EOTR térképei nyújtottak segítséget. A talajtani jellemzők összehasonlításához a Kreybig-féle 1:25000 méretarányú „Átnézetes Talajismereti Térképek"-et használtuk (Kreybig 1934). A térképlapokon egy foltra vonatkoztatva megtaláljuk a fontosabb fizikai és kémiai jellemzőket, a 'Sigmondféle' talajosztályokat, valamint az adott foltok reprezentatív talajszelvényeit, és a heterogenitását jellemző eltérő tulajdonságú talajszelvényeket is (Nagy et al. 2001).

Mivel a földikutyák kizárólag növényi eredetủ táplálékot fogyasztanak, ezért az áttelepítési helyszín növényzeti jellemzői minden bizonnyal hatással lehettek az áttelepített egyedek életére, viselkedésére. Ehhez csak a már rendelkezésre álló növényzeti adatokat volt lehetőségünk használni. Az áttelepítésekben érintett területekről a helyi nemzeti park igazgatóságok biztosították számunkra a Natura 2000 területhálózat egyes részeire vonatkozó fenntartási tervekhez készített növényzeti felmérések adatait (Kerpely 2014, Magura 2014a, 2014b, Szilágyi 2007); segítségükkel összehasonlíthatóvá vált a forrásállományok élőhelyeinek és az új élőhelyeknek a növényzete. A bajai helyszínről Sipos Ferencnek, a Kiskunsági Nemzeti Park Igazgatóság belső vizsgálata keretében végzett növényzeti felmérési adatai nyújtottak segítséget.

A háttéradatok feldolgozása és értékelése során a Quantum GIS programot (QGIS Development Team 2013) használtuk.

\section{Eredmények}

\section{A bagaméri áttelepités értékelése}

A Hajdúsági Tájvédelmi Körzet Kék-Káló menti területének, bagaméri Malomgát nevü részén a 2013-as és a 2014-es évek során összesen 21 földikutyát engedtek szabadon. Az elengedett egyedek közül 9 hím, 12 pedig nőstény volt. A földikutyákat a hajdúhadházi populációból (Liget-legelö) fogták be. Mindkét telepítési évben, az állatok áthelyezését követő első napokban keletkeztek friss túrások. Valamennyi áttelepített egyed túlélte a természetvédelmi beavatkozás okozta stresszhatásokat. Már a 2014-as évben történt párzás az új élőhelyen és fiatal egyedekkel gyarapodott az új populáció (Moldován 2014). Sikerült szaporodóképes állományt létrehozni. A 2016-os állományfelmérés eredményei szerint 
legalább 44, a 2019-es szerint legalább 72 egyed fordul elő a területen. A növekedés nem csupán az egyedszámban volt megfigyelhető, a földikutyák az évek során fokozatosan birtokba vették a területet, mostanra mindenhova eljutottak, ahol száraz homoki gyepek találhatóak.

A befogott földikutya-egyedek áttelepítése révén tehát sikerült életképes, dinamikusan növekedö, önfenntartó földikutya-populációt létrehozni a Nyírség egyik védett területén, Bagamér közelében. Az akció minden előzetes várakozást felülmúlóan sikeresnek bizonyult.

\section{A pocsaji áttelepités értékelése}

Debrecen északi szélén, egy belterületi lucernatáblában 2014 őszén földikutyaállományt találtak (Németh et al. 2020). A szokatlan élőhelyen előkerült populáció fennmaradását közvetlen veszélyforrások fenyegették (Németh et al. 2020), ezért - a sikeres bagaméri akció hatására - a lucernaföldi állomány kimenekítéséről született döntés. A befogott állatok számára - hosszas mérlegelés, valamint számos terület bejárása és vizsgálata után - a Pocsaji-kapu nevü Natura 2000-es terület Löszletörés elnevezésủ része került kiválasztásra. Az eredeti terv a teljes állomány befogása és biztonságos élőhelyre telepítése volt, azonban az élőhely sajátos jellemzőiből fakadóan már a befogások kezdetekor számos váratlan nehézséggel kellett szembesülni. A területen élő földikutyák számát korábban jelentősen alulbecsülték, a járatrendszerek nagymértékben eltértek a korábban megismertektől, a nagy méretü, de óvatos példányok befogása pedig további gondot okozott. Az akció 2015-ben vette kezdetét, és 2018-ig összesen 23 példány földikutya áttelepítésére került sor. Az áttelepített egyedek között 10 hím és 13 nőstény volt.

Az áttelepített egyedek monitoringját további problémák nehezítették. A kiválasztott élőhely szükséges természetvédelmi kezelése csupán részben megoldott. A legeltetés hiánya miatt tavasztól jellemző dús vegetáció következtében évente csak egyetlen időszakban (tél végén, kora tavasszal) van lehetőség az állomány felmérésére. A monitorozás közben megtalált földikutyacsontok tanúsítják, hogy legalább három egyed elpusztult az új élőhelyen. Ugyanakkor a szaporulatra utaló jelek alapján helyben született egyedek is élnek az állományban. Azonban az új populáció egyedszáma stagnál. Biztató, hogy az állomány térben is terjeszkedett, de az egyedszám nagymértékü növekedésének elmaradása, ami Bagamér esetében olyan szembetünő volt, mindenképp problémát jelez. A nehézkes monitoring mellett sem túl valószínü ugyanis, hogy a populáció valós egyedszáma nagyságrendekkel nagyobb lehetne az állományfelmérések során megfigyeltnél. Ezáltal egyértelmű kudarcnak semmiképpen sem tekinthető az akció, és bíztató jelek is ismertek, de még további erőfeszítésekre van szükség, hogy a Löszletörésen is erős, növekvő állomány jöhessen létre. 


\section{Az öttömösi áttelepités értékelése}

A szerb-magyar határ mentén 2015-től kezdődően kiépített határkerítés földikutya-élőhelyeket is fenyegetett. Az építési munkálatok miatt veszélybe került, és ezért eredeti élőhelyükről kimentett egyedek segítségével kísérlet történt egy új földikutya-populáció létrehozására, a Körös-éri Tájvédelmi Körzethez tartozó Öttömösi Baromjárás nevü védett területen. Összesen 17 földikutya áttelepítése történt meg 2016 és 2018 között. Az áthelyezett egyedek között 6 hím és 11 nőstény volt. Már az első példányok elengedését követően jelentkeztek problémák: Az első évben áttelepített 9 egyed közül kettőnek közvetlenül az elengedést követően nyoma veszett. Az ekkor áttelepített állatok többségének ugyanakkor sikerült megtelepednie az új élőhelyen. Az akció kivitelezését azonban nagyban nehezítették azok a szakmai viták, amelyek nyomán gyakorlatilag évről-évre változott az áttelepítés koncepciója és prioritásai, sőt a kivitelezést végző személyek is. A 2017-es évben például ezek következtében mindössze egyetlen példány áttelepítésére került sor, kedvezőtlen időjárási körülmények között, az aktivitási időszak legvégén. A 2018-as évi áttelepítésre vonatkozóan az Agrárminisztérium Természetvédelemért felelős Helyettes Államtitkárságának szakmai tanácsadó szervezeteként működő Földikutya- és Ürgevédelmi Szakértői Csoport alapos szakmai vitát követően, széles szakmai konszenzuson nyugvó, részletes javaslattal állt elő. Sajnos a sok egyeztetés ellenére az áttelepítés kivitelezése során ezektől a javaslatoktól is nagymértékben eltértek.

A monitoring során az állomány gyarapodására, helyben történő szaporodásra vonatkozó adat nem vált ismerté. Az állomány egyedszáma évről-évre lassú, de folyamatos csökkenést mutat. A 2019 tavaszán végzett állományfelmérés során csupán 10 példány jelenlétét sikerült megállapítani. Mindezek alapján nem látszik reális esély arra, hogy egy önfenntartó, a potenciálisan alkalmas élőhely egészét meghódítani képes földikutya-populáció jöjjön létre ezen az élőhelyen.

\section{A bajai áttelepités értékelése}

A Bajai Földikutya Rezervátum közvetlen közelében szükségessé vált egy kisebb töredékállomány kimenekítése egy napelem park építési területéről. A 2017-ben végrehajtott akció során 10 földikutya áttelepítésére került sor a védett terület egy, az akció idején földikutyák által nem lakott részére. Az áttelepített egyedek között 1 hím és 9 nőstény volt. Az akció során a beruházási területen élő valamennyi földikutya befogásra került, és az összes áttelepített egyed mutatott aktivitást az elengedést követően, vagyis nekikezdett saját, új járatrendszere kiépítésének.

A földikutyák elengedését követő eseményeket és azok lehetséges okait részletesen vizsgálták (Schneider et al. 2019). A monitoring adatokból jól látható, hogy az áthelyezett állatok az elengedést követő bő félév folyamán gyakorlatilag 
eltüntek a számukra kiválasztott élőhelyről. 2018 nyarára már csupán legfeljebb 2 példány volt megtalálható a területen. A 2019-es állományfelmérés adatai szerint pedig legjobb esetben is csupán egyetlen földikutya fordulhatott elő a területen. Az áttelepített állomány gyakorlatilag teljes felszámolódását követően aligha várható, hogy új populáció jöhessen létre ezen a területen, az akció sikertelennek tekinthető.

\section{A telepitések sikerességi mutatói és a telepitési útmutatókkal való egyezés mértéke}

Az új földikutya-állományok létrehozását célzó természetvédelmi beavatkozások sikerességi mutatójának kiszámítására kidolgozott értékelési rendszerben a bagaméri populáció létrehozása maximális pontszámot ért el (2. táblázat). A pocsaji telepítés viszont az elérhető összpontszám csupán 67\%-át kapta. Az öttömösi és bajai áttelepítések még rosszabbul szerepeltek, előbbi az elérhető maximális pontszám $25 \%$-át, utóbbi csupán $17 \%$-át érte el.

A sikerek és tanulságok okainak feltárása céljából elvégzett, a telepítési útmutatók ajánlásainak való megfelelés vizsgálata során a következő eredményeket kaptuk: Az IUCN telepítési útmutatójában megfogalmazott ajánlásokkal való egyezés mértékét tekintve (3. táblázat) az öttömösi akció érte el a legmagasabb értéket, 83\%-os egyezést mutatott a javasolt ajánlásokkal. A második legnagyobb mértékủ egyezést, $80 \%$-ot a bagaméri áttelepítés érte el. A pocsaji 77\%-os egyezéssel következik, majd a bajai akció zárja a sort a maga 61\%-os egyezésével. A földikutya-telepítésekhez kidolgozott specifikusabb útmutató ajánlásaival való egyezés meghatározása szolgáló értékelési rendszerben a legmagasabb pontszámot, az elérhető maximális érték 95\%-át a bagaméri telepítés érte el (4. táblázat). A pocsaji akció az elért 83\%-os egyezéssel a második helyen szerepel, majd a bajai telepítés következik a maximálisan elérhető érték 64\%-ával, és a sort az öttömösi telepítés zárja, a megfogalmazott ajánlásokkal mutatott 55\%-os egyezéssel.

\section{A befogási és az áttelepitési helyszinek élőhelyi jellemzőinek összehasonlitása}

A különböző akciók estében nagy különbségeket találhatunk a forráspopulációk élőhelyei és az elengedési helyszínek jellemzői között (1. táblázat). A bagaméri akció során például teljesen azonosak voltak a forrásállomány élőhelyének és az áttelepítési helyszínnek a jellemzői. Tájtörténetük alapján mindkét területen hoszszú idő óta adottak a földikutyák fennmaradása szempontjából nélkülözhetetlen feltételek. A két terület tájképi, domborzati és talajtani tulajdonságai szinte teljesen azonosak, csakúgy, mint a növényzetük. A földikutyák tehát pontosan olyan talajú és domborzatú tájba kerültek, mint ahonnan befogták őket és a rendelkezésükre álló táplálékkínálat is gyakorlatilag azonos volt. 
1. táblázat: A befogási- és az áttelepítési helyszínek jellemzőinek összehasonlítása az egyes áttelepítési akciók esetében.

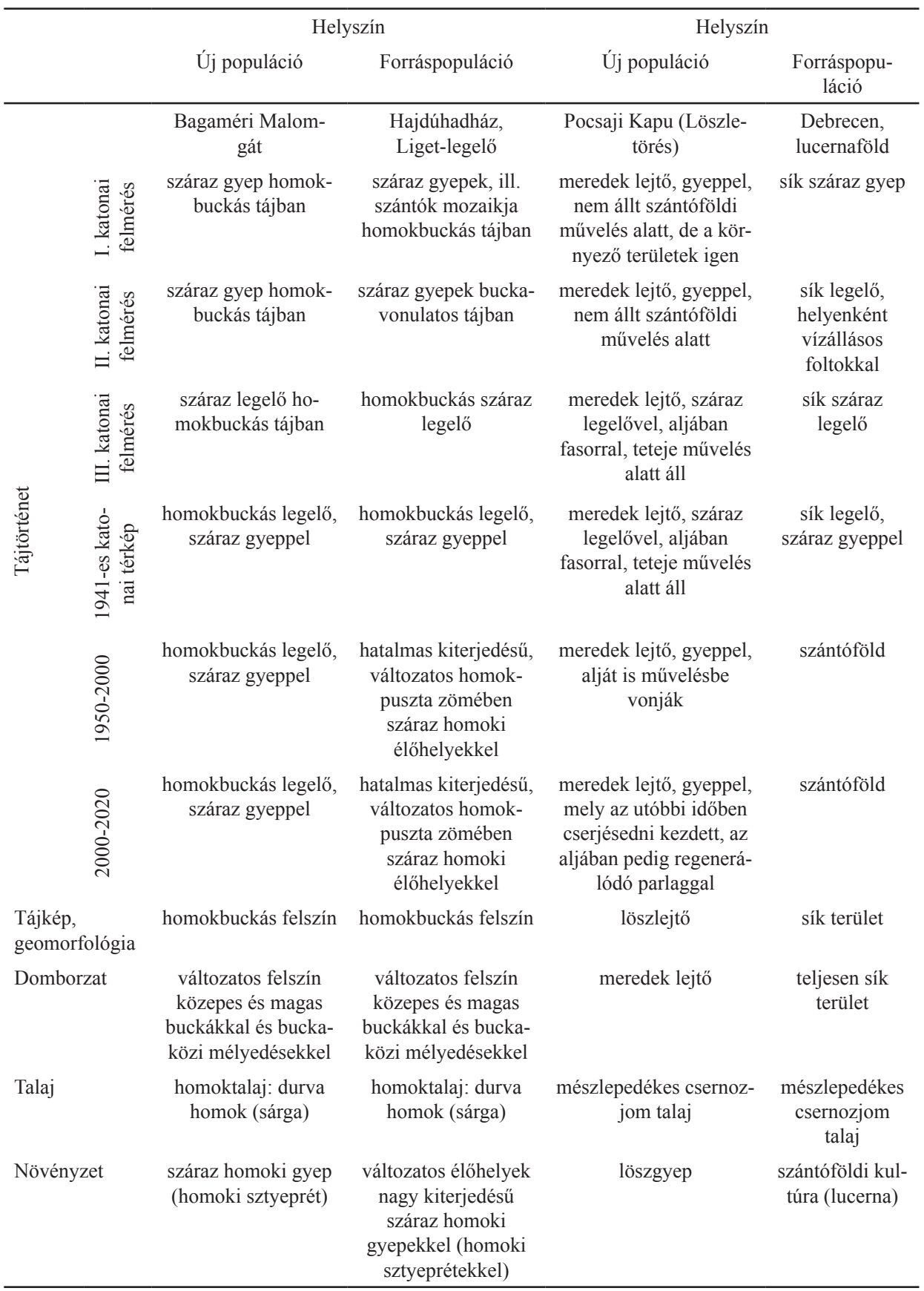


1. táblázat (folytatás): A befogási- és az áttelepítési helyszínek jellemzőinek összehasonlítása az egyes áttelepítési akciók esetében.

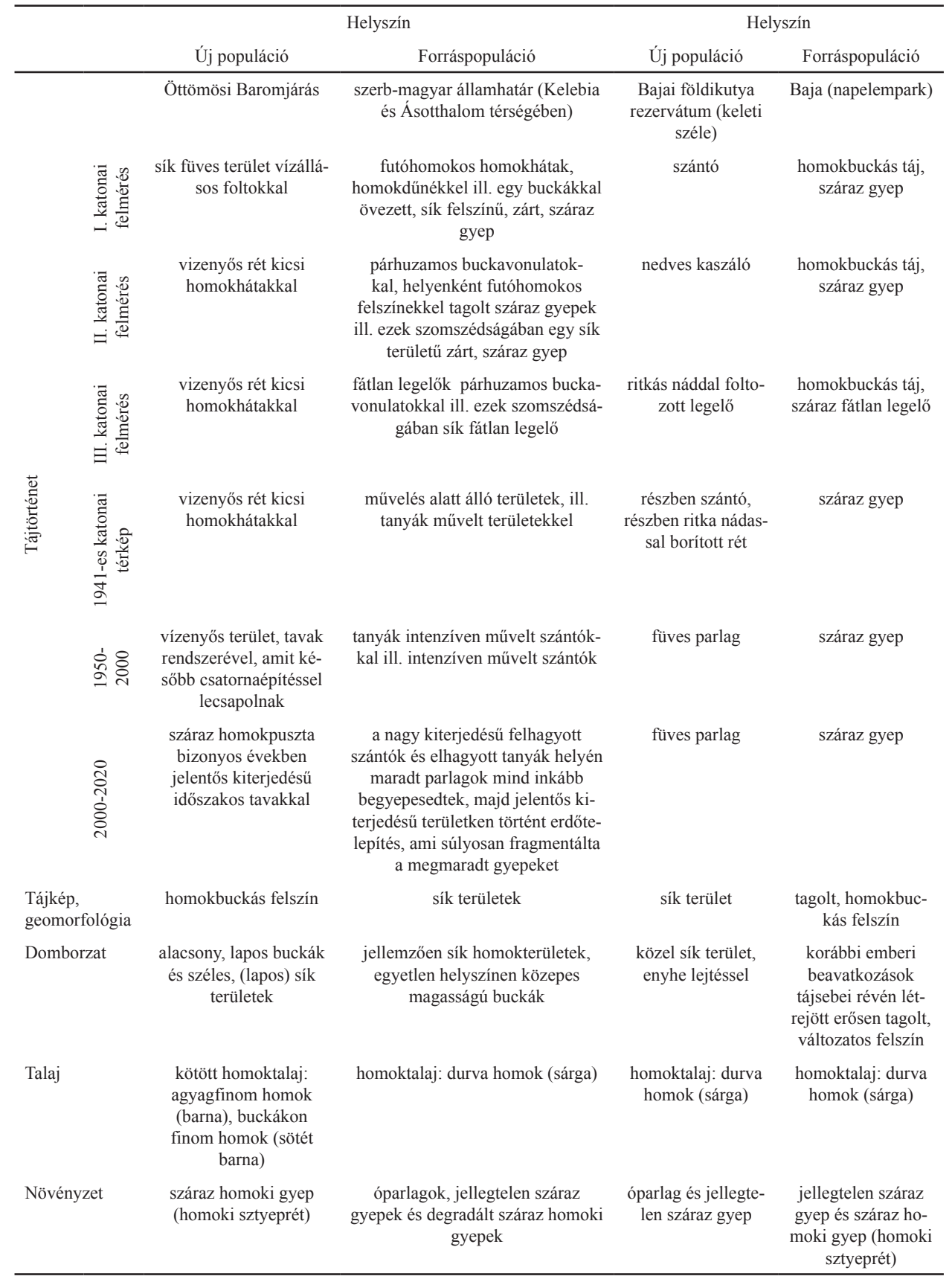


2. táblázat: Az egyes földikutya-áttelepítési akciókhoz tartozó sikerességi mutatók.

\begin{tabular}{lcccc}
\hline \multirow{2}{*}{ Sikerességi kritériumok } & \multicolumn{3}{c}{ Egyes válaszokhoz tartozó pontszámok } \\
& Bagamér & Pocsaj & Öttömös & Baja \\
\hline Szabadonengedett egyedek száma & 2 & 2 & 1 & 0 \\
Hány \% élte túl a telepítést? & 2 & 2 & 1 & 2 \\
Hány \% élte túl az elsó évet? & 2 & 1 & 1 & 0 \\
Szaporodtak-e? & 2 & 1 & 0 & 0 \\
A populáció növekedési rátája & 2 & 1 & 0 & 0 \\
Kialakult-e önnfenntartó populáció? & 1 & 1 & 0 & 0 \\
Egyedszám minimum megduplázódott-e? & 1 & 0 & 0 & 0 \\
Összpontszám & 12 & 8 & 3 & 2 \\
Max. elérhető érték \%-a & $100 \%$ & $67 \%$ & $25 \%$ & $17 \%$ \\
\hline
\end{tabular}

3. táblázat: Az IUCN telepítési útmutatójában megfogalmazott ajánlásokkal való egyezés mértéke az egyes földikutya-áttelepítési akciók tekintetében.

\begin{tabular}{lcccc}
\hline & $\begin{array}{c}\text { Telepítést megelőző } \\
\text { tevékenység }\end{array}$ & $\begin{array}{c}\text { Előkészületek, tervezés } \\
\text { és telepítés }\end{array}$ & $\begin{array}{c}\text { Telepítés utáni } \\
\text { tevékenység }\end{array}$ & Össz. \\
\hline Bagamér & $77 \%$ & $75 \%$ & $97 \%$ & $80 \%$ \\
Pocsaj & $78 \%$ & $75 \%$ & $75 \%$ & $77 \%$ \\
Öttömös & $80 \%$ & $90 \%$ & $81 \%$ & $83 \%$ \\
Baja & $64 \%$ & $63 \%$ & $50 \%$ & $61 \%$ \\
\hline
\end{tabular}

4. táblázat: A földikutya-áttelepítési útmutatóban megfogalmazott ajánlásokkal való egyezés mértéke az egyes földikutya-áttelepítési akciók tekintetében.

\begin{tabular}{|c|c|c|c|c|c|c|c|}
\hline & 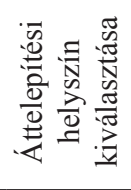 & 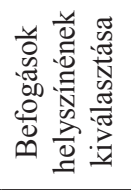 & 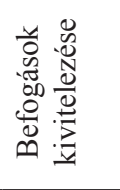 & 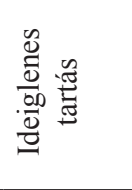 & 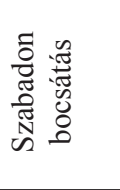 & 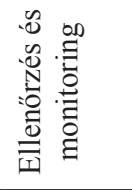 & $\underbrace{\infty}_{0}$ \\
\hline Bagamér & $89 \%$ & $100 \%$ & $96 \%$ & $100 \%$ & $100 \%$ & $100 \%$ & $95 \%$ \\
\hline Pocsaj & $77 \%$ & $60 \%$ & $88 \%$ & $100 \%$ & $100 \%$ & $96 \%$ & $83 \%$ \\
\hline Öttömös & $54 \%$ & $55 \%$ & $46 \%$ & $50 \%$ & $75 \%$ & $57 \%$ & $55 \%$ \\
\hline Baja & $39 \%$ & $80 \%$ & $67 \%$ & $100 \%$ & $92 \%$ & $82 \%$ & $64 \%$ \\
\hline
\end{tabular}


A további áttelepítési akciók során azonban a földikutyák számára az új élőhelyeken már nem voltak ilyen kedvezők a körülmények. A Löszletörésre telepített földikutyák például a korábban megszokottól teljesen különböző viszonyok közé kerültek. Bár talajtani szempontból a két terület nagyon hasonló, de domborzati és növényzeti szempontból jelentősen eltérnek. Míg a lucernaföld egy rendkívül fajszegény, de táplálékban szélsőségesen gazdag élőhely, addig a Löszletörés magas fajgazdagságú, de (legalábbis) a szántóföldi kultúrához képest táplálékban szegényebb élőhely.

Az Öttömös közelébe telepített földikutyák esetében első ránézésre nagyon hasonlónak tünnek a határkerítés mentén elterülő forráspopulációk élőhelyeinek és az áttelepítési helyszínnek a jellemzői. Ez a látszólag nagyfokú hasonlóság vezetett ahhoz, hogy nem is került sor alternatív helyszínek vizsgálatára az áttelepítési helyszín kiválasztása során. Azonban az utólag elvégzett vizsgálatok nagyon is eltérő élőhelyi jellemzőket tártak fel. Míg a befogási helyszínek mind ugyanazon az egykori nagy kiterjedésü, buckás, futóhomokos homokhátságon találhatók, addig az áttelepítési helyszín az előbbitől keletre fekvő, nagy kiterjedésű, lapos és egykor kifejezetten vizenyős területen fekszik. Bár az idők során mind a forrásállományok élőhelyeinek, mind az áttelepítési helyszínnek a képe sokat változott az ember tájátalakító tevékenysége nyomán, a két terület eredetéből adódó különbségek máig meghatározók. A forrásállományok élőhelyein durva homokból álló, világos színű, laza szerkezetủ talajok találhatóak, míg az áttelepítés helyszínén kifejezetten kemény, kötött, agyagfinomságú homokból álló, sötét színủ talaj a jellemző (Kreybig 1934). Mivel azonban az áttelepítési helyszín eredetileg lápos és mocsaras vidékét (kékperjés lápréteket és szikes mocsarakat) teljesen lecsapolták, azon napjainkra száraz homoki növényzet alakult ki, csak kis kiterjedésü foltokban megőrizve az eredeti növényzetet (Gaskó 2006). Így a terület az első, felszínes vizsgálatok alapján (legalábbis növényzeti szempontból) ideális földikutya-élőhelynek látszott.

A bajai akció korábban elvégzett részletes értékelése során kiderült, hogy a kiválasztott áttelepítési helyszín a befogási helytől tájtörténetében, domborzatilag, vízgazdálkodási szempontból és botanikailag is meglehetősen különbözik. Nem tekinthető ideális földikutya-élőhelynek, és táplálékban szegény jellege miatt a legjobb esetben is csak nagyon kis egyedszámú földikutya-állomány eltartására lehet képes (Schneider et al. 2019). 


\section{Diszkusszió}

\section{Attelepitések értékelése: sikerek és tanulságok}

Az egyes áttelepítési akciók sikerességének értékelése alapján a bagaméri populáció létrehozása bizonyult messze a legsikeresebbnek. A második helyre, jóval lemaradva, a pocsaji akció került. Azonban egyáltalán nem egyértelmü, hogy ez az akció sikeresnek mondható-e egyáltalán? Bizonyos jelek bizakodásra adnak okot, de az egyedszám látványos növekedésének elmaradása jelzi, hogy az életképes és önfenntartó földikutya-populáció kialakulásához a legoptimistább forgatókönyv szerint is, hosszabb időre és további természetvédelmi (élőhelykezelési és élőhely rekonstrukciós) beavatkozásokra van szükség. A további akciók esetében azonban inkább a sikertelenség okainak feltárása és a szükséges tanulságok levonása lehet a feladat. Az öttömösi akció csupán az elérhető pontszám negyedét kapta. Az egyedszám csökken, szaporodás valószínüleg sosem történt az új élőhelyen, így sikerről biztosan nem beszélhetünk. A bajai akció még ennél is gyengébb pontszámot ért el, gyakorlatilag eltüntek az áttelepített földikutyák az új élőhelyről, így ebben az esetben sikerességi mutatók számítása nélkül is teljesen egyértelmü az akció kudarca (Schneider et al. 2019).

A sikeresség tekintetében elért nagyon különböző eredményeknek két oka lehet. Okozhatja a rendelkezésre álló, releváns útmutatók ajánlásaitól való eltérés, de az áttelepítésre kiválasztott új élőhely alkalmatlansága is. Az eredmények alapján ugyanakkor az áttelepítések sikeres vagy a kevéssé sikeres voltát nem az akciók során érintett élőhelyek talajtani jellemzői (homok vagy kötött talaj), sem pedig az akciókban részt vevő földikutyák faji hovatartozása határozta meg (Schneider et al. 2019).

\section{Telepitési útmutatók követése}

Olajos (2012) eredményeihez hasonlóan azt találtuk, hogy az útmutatók minél pontosabb követése nagyban hozzájárul egy-egy akció sikerességéhez. Az IUCN telepítési útmutatójában foglalt ajánlások követésének vizsgálata azonban meglepő eredményt hozott, ennek alapján az öttömösi telepítés érte el a legmagasabb értéket. Tekintve, hogy ez az akció a sikeresség értékelése során kifejezetten alacsony pontszámot kapott, és sikeresnek így egyáltalán nem tekinthető, az eredmény további magyarázatra szorul. Az öttömösi telepítés az alábbi kritériumok alapján ért el kimagasló pontszámot: a helyi lakosság bevonása, a szocio-ökonómiai vizsgálatok megléte, valamint a hosszútávú finanszírozás biztosítottsága az új állomány fenntartása érdekében. Az akció egy Európai Unió által finanszírozott LIFE projekt keretében valósult meg (Németh et al. 2018), így alapvető elvárás volt ezen feltételek teljesítése. A többi áttelepítés során viszont ezek nem voltak hangsúlyo- 
sak. Alapvetően ezek mind fontos szempontok, különösen egy univerzális, bármely fajra alkalmazható útmutatóban, az akciók sikerességének értékelése során azonban láthattuk, hogy ezek a szempontok nem meghatározó feltételei a sikeres földikutya-telepítésnek. A földikutyák ugyanis nagyon sajátos életmódot folytató állatok, melyek élőhelyük zavartalansága esetén gyakorlatilag semmilyen interakcióba nem kerülnek a helyi lakossággal. Ezért védett területre történő telepítés esetén a helyi közösséggel kialakított pozitív kapcsolat nem tud jelentősen hozzájárulni az akció sikeréhez. Ugyanakkor általánosságban megállapítható, hogy az IUCN útmutatójának minél pontosabb követése hozzájárulhat ahhoz, hogy egy földikutya-áttelepítési akció sikeres legyen.

A földikutya-telepítési útmutató javaslataival való egyezés mértéke jobb egyezést mutat a telepítések sikerességének sorrendjével. A földikutya-áttelepítések annál sikeresebb voltak, minél pontosabban betartották az útmutató javaslatait. Az ajánlások minél pontosabb betartása, az iránymutatások minél alaposabb követése biztosítékot jelenthet új földikutya-populációk sikeres létrehozására. Ezért az elmúlt időszakban szakmai körökben felmerült véleménnyel szemben nem a földikutya-telepítési útmutató módosítására, sokkal inkább a benne foglaltak minél következetesebb betartására lenne szükség a sikeresebb földikutya-áttelepítések érdekében.

Jellemzően sikertelennek bizonyultak az akciók, ha az útmutató eredeti koncepciójától eltérve egy állomány teljes áttelepítésével, kimenekítésével próbálkoztak. Az útmutató létrehozásának eredeti célja ugyanis az volt, hogy elősegítse a földikutyafajok helyzetének javítását azáltal, hogy erős, stabil populációkból befogott egyedek áttelepítése révén potenciálisan alkalmas és védhető élőhelyeken új földikutya-populációkat hoznak létre (Németh et al. 2013b). Veszélybe került földikutya-populációk sikeres áttelepítése azonban az eddigi eredmények szerint nem megvalósítható. Ezekben az esetekben például, mivel nem nagy és stabil populációkból történik a befogás, nehéz a kellő számú egyed megfogása, és nagyobb az elhullás veszélye is. Így azonban nem sikerül kellő számú és megfelelő ivararányú állományt telepíteni az új élőhelyre, ami viszont az új populáció megalapítása szempontjából kritikus jelentőségü lenne. Az elmúlt évek tapasztalatai mindezt kellően igazolták, egyetlen mentőakció-jellegü áttelepítés sem ért el egyértelmü sikert. A földikutya-állományokat a jelenlegi tudásunk mellett, úgy tünik, csakis az eredeti élőhelyükön tudjuk megőrizni, veszélyeztetett élőhelyekről biztonságosabbra telepítésükhöz egyelöre nincsen bevált módszer (Németh et al. 2020).

\section{Attelepitési helyszín kiválasztása}

Ha megvizsgáljuk, mely pontokban tértek el leginkább a kevéssé sikeres akciók a földikutya-telepítési útmutató javaslataitól, azt láthatjuk, hogy a forráspopuláció 
kijelölésének kérdése mellett a létrehozandó populáció élőhelyének kiválasztása okozta a legtöbb problémát. A kijelölt áttelepítési helyszín körüli gondok a bagaméri telepítésen kívül minden akció esetében felmerültek. Bár láthatunk példát arra is, hogy a kijelölt helyszín teljesen alkalmatlan a földikutyák számára, gyakoribb, hogy az élőhely alapvetően megfelelő, de a forrásállomány élőhelyétől olyan mértékben különbözik, ami már komoly nehézséget jelent a megtelepedés első, kritikus fázisában. A pocsaji áttelepítés esetében pontosan ez történt. Mindez pedig elegendő volt ahhoz, hogy az útmutató ajánlásainak követése mellett is jelentősen rontsa az akció sikerességének mértékét. Az öttömösi akció esetében a probléma összetettebb, mert bár ennek az akciónak a során követték legkevésbé az útmutató ajánlásait, de az élőhely sem tekinthető teljesen megfelelőnek. A bajai telepítés során alapvetően sikerült az útmutató szerint eljárni, de a szerencsétlen helyszínválasztás miatt (ami valószínúleg egyáltalán nem volt alkalmas földikutyák számára), az áttelepítés sikertelenül zárult (Schneider et al. 2019).

Ugyanakkor mindezek ellenére a különböző akciók során nagyon különböző mértékü erőfeszítések történtek a probléma megoldására. A pocsaji áttelepítés esetében például egy éven át tartó vizsgálatokat követően több mint tíz helyszínből választották ki a végsőt. Ezzel szemben a bajai kimenekítés alatt mindössze három helyszín közül, de igazán átfogó vizsgálatok nélkül történt a választás. Öttömös esetében viszont fel sem merült alternatív helyszín(ek) lehetősége. Mindezekből az is látható, hogy a mentőakció-jellegü telepítések közepette mennyire korlátozottak a lehetőségek az új élőhely kiválasztására. Stabil állományból létrehozott új populáció kialakítása közben sokkal szabadabban dönthetnek a szakemberek, a lehetséges helyszínek széles spektrumát megvizsgálva. A szóba jöhető forráspopulációk és a lehetséges áttelepítési helyszínek között keresgélve összepárosítható az egymáshoz leginkább hasonlító két élőhely. De veszélyeztetett egyedek kimenekítése során minderre nincsen lehetőség: rövid idő alatt, alapos vizsgálatok nélkül kell dönteni, ami ritkán vezet sikerhez.

\section{További veszélyforrások}

$\mathrm{Az}$ áttelepítések során felmerülő eltérő szakmai álláspontok és nézetkülönbségek nem kedveznek az akciók sikerének. A szakmai viták okozta kényszerü, kompromisszumos döntések negatív következményei a bajai áttelepítés értékelése során egyértelművé váltak (Schneider et al. 2019). Hasonló jelenséget láthatunk ugyanakkor az öttömösi áttelepítés esetében is, ahol jelentős koncepcionális változások következtek be az akció megvalósítása során. Eredetileg egy a bagamérihoz hasonló akció terve merült fel, ahol a Kelebia és Ásotthalom közötti populációból származó egyedekkel hoztak volna létre új populációt. A terv szerint az apró töredékállományok mindegyikéből csak egy-két egyed befogására lett volna 
szükség, így a szükséges egyedszám összegyüjtése nem fenyegette volna egyik szub-populáció fennmaradását sem. A védett területen létrejövő új állomány garantálhatta volna az eredeti populáció egészének genetikai fennmaradását. Ezt a koncepciót a Földikutya- és Ürgevédelmi Szakértői Csoport is támogatta 2015ben. Azonban a szerb-magyar határra épülő határkerítés okozta fenyegetés miatt az eredeti koncepció megváltozott, az akció kezdetekor már a veszélyeztetett egyedek kimenekítése vált a fó prioritássá. Így az eredeti cél már a telepítés első évében is csak részben valósulhatott meg. Később viszont komoly szakmai vitákhoz vezetett annak eldöntése, hogy az eredeti koncepcióhoz való visszatérés, vagy pedig a veszélyeztetett, esetleg csak nehezen védhető töredékállományok teljes áttelepítése legyen a cél. A Földikutya- és Ürgevédelmi Szakértöi Csoport több ülésén is napirendre került a téma, amit heves szakmai viták öveztek. Az így született kompromisszumos megoldások következtében egyre nehezebbé vált az akciót a földikutya-telepítési útmutató ajánlásainak megfelelően megvalósítani.

Nehéz reálisan megítélni az öttömösi áttelepítés végeredményét. Az eddigi áttelepítési akció kétségkívül súlyosan elhibázott volt: a forrásállomány kiválasztása és a kivitelezés módja is problémás volt. Mindez pedig minimum szuboptimális, de talán alkalmatlan élőhelyen történt, ahol aligha várható, hogy életképes, önfenntartó populáció jöjjön létre. Ugyanakkor, a rendelkezésre álló ismeretek alapján az Öttömösi Baromjárás nevú védett területnek lehet olyan része, amelyen talán lehetséges életképes populáció megalapítása. A kérdés további alapos vizsgálata mindenképpen javasolt. A kelebiai és ásotthalmi élőhelyeken élő földikutya-populációval azonban nagyon súlyos genetikai problémák is vannak (Sramkó 2019), ami miatt forráspopulációként való alkalmasságuk is mérlegelésre szorul.

\section{Konklúzió és javaslatok}

Új földikutya-populáció létrehozására irányuló áttelepítések során legfontosabb az alapos tervezés még jóval az akció megkezdése elött. Részletes és pontos terv kidolgozása szükséges az áttelepítés egészét illetően. A kidolgozott koncepciótól pedig az akció kezdetét követően már semmiképpen nem javasolt eltérni. A menet közben született új ötletek, a koncepció újraértelmezése, az ehhez társuló szakmai viták, és az azok eredményeként hozott kényszerü kompromisszumok nagyon nagy mértékben veszélyeztetik az egész akció sikerét.

Egy új földikutya-populáció létrehozásához az alkalmas új élőhely kiválasztása a legfontosabb, de egyben legnehezebb feladat. Ennek során az új élőhely földikutyák szempontjából való biológiai, ökológiai alkalmassága kell, hogy legyen a fó szempont, a potenciális új élőhelyek jogi státuszával szemben (Schneider et al. 2019). Az alkalmas befogadó élőhely megtalálását követően a telepítés sikere 
érdekében a teljes akció során minél pontosabban követni kell a földikutya-telepítési útmutató ajánlásait.

Az eddigi tapasztalatok alapján nem ismert olyan módszer, mellyel reális esélye lehetne veszélyeztetett földikutya-állományok sikeres áttelepítésnek - bármennyire is fontos is lenne ez a gyakorlati természetvédelemi munka során. Így a helyben való megőrzés fontosságát szükséges hangsúlyozni (Németh et al. 2020).

Köszönetnyilvánitás - Köszönettel tartozunk a Hortobágyi és a Kiskunsági Nemzeti Park Igazgatóságok munkatársainak, amiért munkánkat nem csupán lehetővé tették, de nagymértékben segítették is. További köszönettel tartozunk a Magyar Természettudományi Múzeumnak, és különösen Dr. Csorba Gábornak a vizsgálatok során nyújtott sokrétủ és pótolhatatlan segítségért. Szeretnénk köszönetet mondani Fidlóczky Józsefnek a kézirat minőségének javítása érdekében tett javaslataiért és tanácsaiért. A bemutatott munka és az eredmények részben az Európai Unió LIFE17 IPE/HU/000018 számú pályázatának támogatásából megvalósuló „Grassland LIFE IP” projekt keretében jöttek létre.

\section{Irodalomjegyzék}

Andrési, P. (2002): Cselekvö természetvédelem. - Magyar Madártani és Természetvédelmi Egyesület - Orchis Természetvédelmi Egyesület, Budapest - Ásotthalom, 266 p.

Baillie, J. \& Cokeliss, Z. (2004): Extinctions in recent time. - In: Baillie, J., Hilton-Taylor, C. \& Stuart, S. N. (eds.): IUCN Red List of Threatened Species: A Global Species Assessment, IUCN, Gland - Cambridge, pp. 33-50.

Bajomi, B. (2003): Veszélyeztetett állatfajok visszatelepitésének eredményességét befolyásoló tényezök: a kékcsörü réce és az eurázsiai hód magyarországi visszatelepitésének összehasonlitó elemzése. - MSc diplomamunka, Eötvös Loránd Tudományegyetem, Budapest, 79 p.

Bajomi, B., Bera, M., Czabán, D. \& Gruber, T. (2016). Eurasian beaver re-introduction in Hungary. - In: Soorae, P. S. (ed.): Global re-introduction perspectives: 2016. Case-studies from around the globe. IUCN/SSC Re-introduction Specialist Group, Environmental Agency, Gland - AbuDhabi, pp. 211-215.

Barnosky, A. D., Matzke, N., Tomiya, S., Wogan, G. O., Swartz, B., Quental, T. B., Marshall, C., McGuire, J. L., Lindsey, E. L., McGuire, K. C., Mersey, B. \& Ferrer, E. A. (2011): Has the Earth's sixth mass extinction already arrived? - Nature 471: 51-57. https://doi.org/10.1038/nature09678

Beck, B. B., Rapaport, I. G., Stanley-Price, M. R. \& Wilson, A. C. (1994): Reintroduction of captive reared animals - In: Olney, P. J. S., Mace, J. M. \& Feistner, A. T. C. (eds.): Creative Conservation: Interactive management of wild and captive animals. Chapman \& Hall, London, pp. 265-286.

Ceballos, G., García, A. \& Ehrlich, P. R. (2010): The sixth extinction crisis: loss of animal populations and species. - Journal of Cosmology 8: 1821-1831.

Csorba, G., Krivek, G., Sendula, T., Homonnay, Z. G., Hegyeli, Zs., Sugár, Sz., Farkas, J., Stojnić N. \& Németh, A. (2015): How can scientific research change conservation priorities? - A review of decade-long research on blind mole rats (Rodentia: Spalacinae) in the Carpathian Basin. Therya, 6: 103-121. https://doi.org/10.12933/therya-15-245 
Dirzo, R., Young, H. S., Galetti, M., Ceballos, G., Isaac, N. J. \& Collen, B. (2014): Defaunation in the Anthropocene. - Science 345: 401-406. https://doi.org/10.1126/science.1251817

Fidlóczky, J., Szitta, T., Nagy, L., Dudás, M., Fidlóczky, Zs., Tokaji, K., Altbäcker, V., Németh, A. \& Cserkész, T. (2017): Sikerek és tanulságok: Három évtized ürge-áttelepítéseinek tapasztalatai - In: Mizsei, E. \& Szepesváry, Cs. (szerk.): „, Sikerek és Tanulságok a természetvédelemben” XI. Magyar Természetvédelmi Biológiai Konferencia, Absztrakt-kötet. Magyar Biológiai Társaság MTA Ökológiai Kutatóközpont, pp. 34-35.

Gaskó, B. (2006): Javaslatok természetes és természetközeli élöhelyek védelmére a kiskunsági homokhát délkeleti felében (Kelebia, Öttömös, Ásotthalom, Mórahalom). - Kutatási jelentés, Szeged, $193 \mathrm{p}$.

Griffith, B., Scott, J. M., Carpenter, J. W. \& Reed, C. (1989): Translocation as a species conservation tool: Status and strategy. - Science 245: 477-480. https://doi.org/10.1126/science.245.4917.477

Hadarics, T. (2011): Rudolf trónörökös, az ornitológus. - Ornis Hungarica 19: 149-163.

IUCN/SSC (1998): IUCN Guidelines for Re-introductions. - IUCN, Gland - Cambridge, $11 \mathrm{p}$.

IUCN/SSC (2013): Guidelines for Reintroductions and Other Conservation Translocations. Version 1.0. - IUCN Species Survival Commission, Gland, viiii +57 p.

Kerpely, K. (2014): Déli-homokhátság (HUKN20008) kiemelt jelentőségü természetmegőrzési terület. - Natura 2000 Fenntartási Terv, WWF Magyarország, Budapest, 93 p.

Kreybig, L. (1934): A M. Kir. Földtani Intézet talajfelvételi, vizsgálati és térképezési módszere és célja. - A Magyar mérnök és Épitész Egylet Közlönyének Havi Füzetei 12., 31 p.

Lee, R. \& Hughes, B. (2008): Review of Waterbird Re-establishment in the AEWA region. Research report to AEWA. Wildfowl \& Wetlands Trust, Slimbridge, Gloucestershire, $107 \mathrm{p}$.

Magura, T. (szerk.) (2014a): A Kék-Kálló-völgye (HUHN20016) kiemelt jelentöségü természetmegörzési terület fenntartási terve. - Natura 2000 Fenntartási Terv, Hortobágyi Nemzeti Park Igazgatóság, Debrecen, $44 \mathrm{p}$.

Magura, T. (szerk.) (2014b): A Pocsaji-kapu (HUHN20010) kiemelt jelentöségü természetmegörzési területfenntartási terve. - Natura 2000 Fenntartási Terv, Hortobágyi Nemzeti Park Igazgatóság, Debrecen, $37 \mathrm{p}$.

Márkus, F. (2004): Gerinces állatfajok visszatelepítésének természetrajza Magyarországon, 1970tól napjainkig. - Termvéd Közlem. 11: 359-369.

McGill, B. J., Dornelas, M., Gotelli, N. J. \& Magurran, A. E. (2015): Fifteen forms of biodiversity trend in the Anthropocene. - Trends Ecol. Evol. 30: 104-113. https://doi.org/10.1016/j. tree.2014.11.006

Moldován, O. (2014): Az erdélyi földikutya Nannospalax (leucodon) transsylvanicus új populációjának létrehozása és az első év tapasztalatai. - Diplomamunka, Debreceni Egyetem, Debrecen, $44 \mathrm{p}$.

Nagy, J., Németh, T., Szabó, J., Pásztor, L. \& Dobos, A. (2001): Tájgazdálkodási körzetek kialakítása a Kreybig-féle „Átnézetes Talajismereti Térképsorozat” alapján. - Acta Agraria Debreceniensis 1: 20-25.

Németh, A., Farkas, J., Krnács, Gy. \& Csorba, G. (2010): KvVM Fajmegőrzési tervek: Nyugati földikutya (Nannospalax leucodon). - KvVM Természetvédelmi Szakállamtitkárság, Budapest, 31 p.

Németh, A., Csorba, G., Farkas, J., Krnács, Gy., Molnár, A., Boldogh, G. \& Szelényi, B. (2013a): VM Fajmegörzési tervek: Kárpát-medencei Nyugati földikutya kisfajok (Nannospalax (superspecies leucodon)). - VM Környezetügyért Felelős Államtitkárság, Budapest, 68 p. https://doi. org/10.13140/RG2.2.25180.59529

Németh, A., Molnár, A., Szél, L., Horváth, T., Demeter, L. \& Csorba, G. (2013b): Hogyan telepítsünk át földikutyát? Módszertani megfontolások szélsőségesen talajlakó rágcsálók megmentéséhez. - Termvéd Közlem. 19: 15-33. 
Németh, A., Cserkész, T., Nagy, L., Altbäcker, V., Horváth, M., Prommer, M. \& Váczi, O. (2018): RaptorsPrey LIFE project (LIFE13 NAT/HU/000183/b) - Layman's report (2014-2018). Nimfea Nature Conservation Society, Túrkeve, $28 \mathrm{p}$.

Németh. A., Moldován, O. \& Szél, L. (2020): Mindig útban? - Városias környezetben fennmaradt földikutya-állományok megörzésének kihívásai Magyarországon. - Termvéd Közlem. 26: 52-69. https://doi.org/10.20332/tvk-jnatconserv.2020.26.52

Olajos, T. (2012): A magyarországi állatfaj-visszatelepitések elemzése az IUCN útmutató alapján. - BSc diplomamunka, Szent István Egyetem, Természetvédelmi és Tájökológiai Tanszék, Gödöllö, 59 p.

Pullin, A. S. \& Bajomi, B. (2008): Are we doing more good than harm? Evaluating effectiveness of nature restoration policy in Europe. - In: Sixth European Conference on Ecological Restoration. Ghent, pp. 1-5.

QGIS Development Team (2013): QGIS Geographic Information System. - Open Source Geospatial Foundation Project. http://qgis.osgeo.org

Rado, R., Wollberg, Z. \& Terkel, J. (1992): Dispersal of young mole rats (Spalax ehrenbergi) from the natal burrow. - J. Mammal. 73: 885-890. https://doi.org/10.2307/1382211

Rakonczay, Z. (szerk.) (1989): Vörös Könyv: a Magyarországon kipusztult és veszélyeztetett növény-és állatfajok. - Akadémiai Kiadó, Budapest, 360 p.

Reading, R. P. \& Kellert, S. R. (1993): Attitudes toward a proposed reintroduction of black footed ferrets (Mustela nigripes). - Conserv. Biol. 7: 569-580. https://doi.org/10.1046/j.15231739.1993.07030569.x

Schneider, V., Ruzsa, J., Czabán, D. \& Németh A. (2019): Egy földikutya-áttelepítés tanulságai. Termvéd Közlem. 25: 14-33. https://doi.org/10.20332/tvk-jnatconserv.2019.25.14

Seddon, P. J. (1999): Persistence without intervention: assessing success in wildlife reintroductions. - Trends Ecol. Evol. 14: 503. https://doi.org/10.1016/S0169-5347(99)01720-6

Seddon, P. J., Armstrong, D. P \& Maloney, R. F. (2007): Developing the science of reintroduction biology. - Conserv. Biol. 21: 303-312. https://doi.org/10.1111/j.1523-1739.2006.00627.x

Sramkó, G. (2019): Délvidéki földikutya-állományok (Nannospalax montanosyrmiensis) filogeográfiai és populációgenetikai szerkezetének feltárása, genetikai állapotának értékelése céljából de novo SSR fejlesztés az új generációs módszerekkel. - Kutatási jelentés, Mikepércs, 24 p.

Sterbetz, I. (1979): Élö örökségünk. Génerózió, génbank. - Mezőgazdasági Kiadó, Budapest, 194 p.

Szilágyi, G. (szerk.) (2007): A Liget-legelö (Geszteréd, Hajdúhadház, Hajdúsámson) javasolt kiemelt jelentőségü természetmegörzési terület természetvédelmi fenntartási terve. - Natura 2000 Fenntartási Terv, Hortobágyi Nemzeti Park Igazgatóság, Debrecen, 76 p.

Topachevskii, V. A. (1969): Fauna of the USSR: Mammals. Mole rats, Spalacidae. - Smithsonian Institution and the National Science Foundation, Washington, $308 \mathrm{p}$.

Vásárhelyi, I. (1926): Adatok a földikutya (Spalax hungaricus hungaricus Nhrg.) életmódjának ismeretéhez. - Állattani Közlem. 23:169-226.

Vida, G. (2018): Csökkenő biodiverzitás, növekvő gazdaság. Meddig? - In: Tardy J. \& Dévai Gy. (szerk.): A biodiverzitásról másképp. Magyar Természettudományi Társulat, Budapest, pp. 1425.

Vidacs, J. A., Farkas, J. \& Németh, A. (2013): Konvergenciák, divergenciák és adaptáció a talajlakó életmódot folytató emlösöknél. - Állattani Közlem. 98: 21-46.

Wolf, C. M., Griffith, B., Reed, C. \& Temple, S. A. (1996): Avian and mammalian translocations: update and reanalysis of 1987 survey data. - Conserv. Biol. 10: 1142-1154. https://doi. org/10.1046/j.1523-1739.1996.10041142.x 
Internetes térképforrások

http1: I. Katonai Felmérés (1782-85): HM Hadtörténeti Intézet és Múzeum Térképtára, Arcanum

Adatbázis Kft., Budapest. http://mapire.eu/hu/map/firstsurvey/

http2: II. Katonai Felmérés (1806-1869): HM Hadtörténeti Intézet és Múzeum Térképtára, Arcanum

Adatbázis Kft., Budapest. http://mapire.eu/hu/map/secondsurvey/

http3: III. Katonai Felmérés (1869-1887): HM Hadtörténeti Intézet és Múzeum Térképtára, Arca-

num Adatbázis Kft., Budapest. http://mapire.eu/hu/map/thirdsurvey25000/

http4: II. Világháborús Katonai Felmérés (1941): HM Hadtörténeti Intézet és Múzeum Térképtára,

Arcanum Adatbázis Kft., Budapest. http://mapire.eu/hu/map/hungary1941/

http5: 1959-2007 időszakból származó légifelvételek: Digitális légifelvétel archívum, Lechner

Nonprofit Kft. légifilmtára (FÖMI, Budapest) https://www.fentrol.hu/hu/

\section{Evaluation of the Hungarian blind mole rat translocation projects}

\section{János Ruzsa1 ${ }^{1}$ Viktor Schneider ${ }^{2}$, János Farkas ${ }^{1}$ \& Attila Németh ${ }^{3,4}$}

${ }^{1}$ Eötvös Loránd University, Department of Systematic Zoology and Ecology H-1117 Budapest, Pázmány Péter stny. 1/C, Hungary

${ }^{2}$ Szent István University, Faculty of Agriculture and Environmental Sciences, H-2100 Gödöllö, Páter Károly u. 1., Hungary

${ }^{3}$ BirdLife Hungary - Hungarian Ornithological and Nature Conservation Society, H-1121 Budapest, Költö u. 21., Hungary

${ }^{4}$ Hungarian Natural History Museum, H-1088 Budapest, Baross u. 13., Hungary

E-mail:dr.attila.nemeth@gmail.com

Lesser blind mole rats, Nannospalax (superspecies leucodon) are among the most threatened mammals of Hungary. Because of theirs special lifestyle, the conservation of blind mole rats is especially challenging for nature conservation. Since 2013, a conservation program is underway in order to increase the number of the local blind mole rat populations. Four new populations have been established in the vicinity of different localities, in order of the year started: Bagamér (2013), Pocsaj (2015), Öttömös (2016) and Baja (2017). In this paper we are not only evaluating the success of each action, but we also try to find an explanation for the significant differences among the results of these actions. The features of the relocation site turned out to be just as important as the proper implementation of the recommendations of the blind mole rat translocation protocol. The presented results may contribute to successful conservation measurements in the future.

Keywords: Nannospalax (superspecies leucodon), habitat suitability analysis, monitoring, Bagamér, Pocsaj, Öttömös, Baja 